\title{
Phenomena Identification and Ranking Technique (PIRT) Panel Meeting Summary Report
}

\author{
Mark Holbrook
}

July 2007

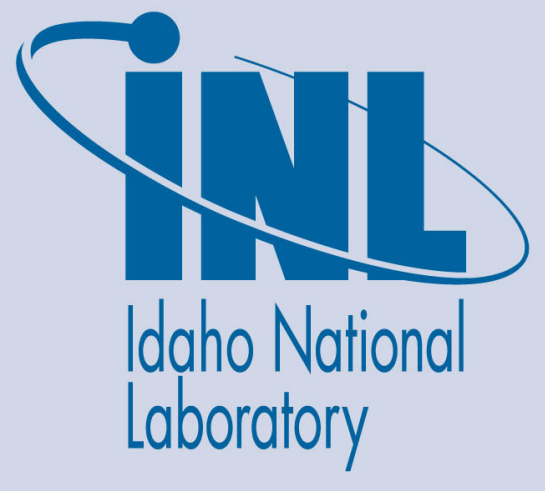

The INL is a U.S. Department of Energy National Laboratory operated by Battelle Energy Alliance 
INL/EXT-12-25290

\title{
Phenomena Identification and Ranking Technique (PIRT) Panel Meeting Summary Report
}

\author{
Mark Holbrook
}

July 2007

\section{Idaho National Laboratory Next Generation Nuclear Plant (NGNP) Project Idaho Falls, Idaho 83415}

http://www.inl.gov

Prepared for the

U.S. Department of Energy

Office of Nuclear Energy

Under DOE Idaho Operations Office

Contract DE-AC07-05ID14517 


\section{CONTENTS}

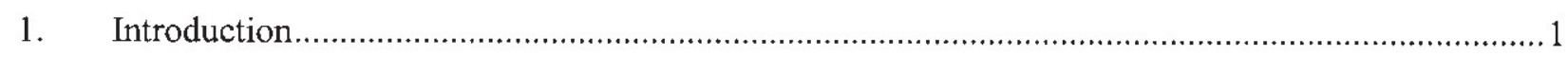

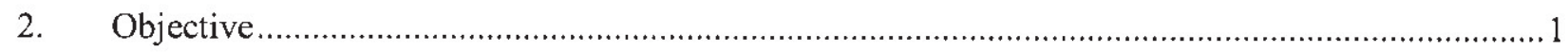

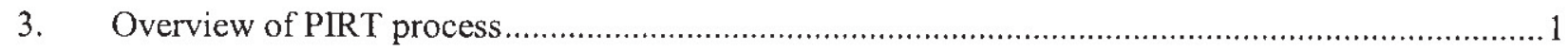

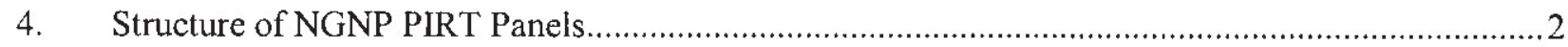

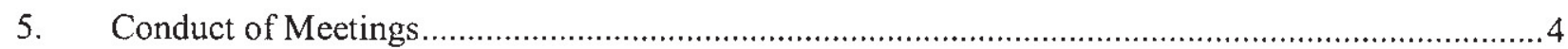

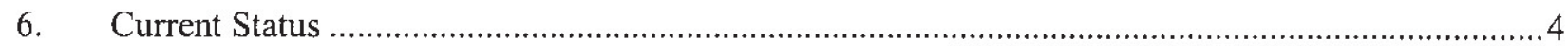

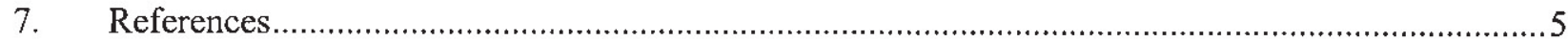




\section{Introduction}

Section 644(b) of the Energy Policy Act of 2005 (EPAct) states: "Not later than 3 years after the date of enactment of this Act, the Secretary and the Chairman of the Nuclear Regulatory Commission shall jointly submit to the appropriate committees of the Senate and the House of Representatives a licensing strategy for the prototype nuclear reactor, including -

1) a description of ways in which current licensing requirements relating to light-water reactors need to be adapted for the types of prototype nuclear reactor being considered by the Project;

2) a description of analytical tools that the Nuclear Regulatory Commission will have to develop to independently verify designs and performance characteristics of components, equipment, systems, or structures associated with the prototype nuclear reactor;

3) other research or development activities that may be required on the part of the Nuclear Regulatory Commission in order to review a license application for the prototype nuclear reactor; and

4) an estimate of the budgetary requirements associated with the licensing strategy."

As a result of the tasks included in the EPAct, a working group was formed that consisted of personnel from the Department of Energy (DOE), the Nuclear Regulatory Commission (NRC) and the Idaho National Laboratory (INL). This group, the "NGNP Licensing Strategy Working Group," was given the task of developing the report to Congress addressing the four areas listed above.

\section{Objective}

NRC, in collaboration with DOE and the working group, conducted the Phenomena Identification and Ranking Technique (PIRT) exercises to identify safety-relevant phenomena for NGNP, and to assess and rank the importance and knowledge base for each phenomenon. The overall objective was to provide NRC with an expert assessment of the safety-relevant NGNP phenomena, and an overall assessment of R\&D needs for NGNP licensing. The PIRT process was applied to five major topical areas relevant to NGNP safety and licensing: 1) thermofluids and accident analysis (including neutronics), 2) fission product transport, 3) high temperature materials, 4) graphite, and 5) process heat for hydrogen cogeneration.

\section{Overview of PIRT process}

PIRT is a systematic way of gathering information from experts on a specific subject, and ranking the importance of the information, in order to meet some decision-making objective, e.g., determining what has highest priority for research on that subject.

The PIRT process results in lists of phenomena which are associated with a particular subject (a specific figure-of-merit). The phenomena can actually be the condition of a particular 
reactor/system/component, a physical or engineering approximation, a reactor parameter, or anything else that might influence the figure-of-merit. The process proceeds by ranking these phenomena using some scoring criteria in order to help determine what is most important. That ranking, as well as the rationale for the ranking along with the information obtained to explain the ranking, can assist in decision making. The PIRT methodology brings into focus the phenomena that dominate an issue, while identifying all plausible effects to demonstrate completeness. [1]

An important part of the process is to also identify the uncertainty in the ranking, usually by scoring the knowledge base for the phenomenon. Again the rationale for the scoring is an important product of the elicitation. When a phenomenon is identified as being important but the corresponding knowledge level is low it is an indication that more effort must be applied, e.g., more research support. [1]

\section{Structure of NGNP PIRT Panels}

The expert panels were organized around the five areas listed in Section 1 (above). NRC and DOE, personnel developed lists of acknowledged experts in each of the fields represented by the five panel topics and invitations were extended to the recommended panelists. Panel participants included 25 experts from Argonne National Laboratory (ANL), INL, Oak Ridge National Laboratory (ORNL), Sandia National Laboratory (SNL), Savannah River National Laboratory (SRNL), Commissariat à l'énergie atomique (CEA), Institut de Radioprotection et de Sûrenté Nucléaire (IRSN), Massachusetts Institute of Technology (MIT), Texas A\&M, University of Manchester (UK), and University of Wisconsin. In addition, gas reactor technical experts from Areva, General Atomics, Technology Insights, and Westinghouse were invited to provide design information to the panelists, but were not allowed to vote during panel deliberations.

The panels were organized as follows:

- Thermal-fluidics Panel - The objectives of the thermofluids and accident analysis PIRT were to identify safety-relevant phenomena for normal plant operation and postulated accident scenarios, and then rank them for their importance with regard to established evaluation criteria or figures of merit (FOMs). The PIRT panel focused on the thermal fluid aspects of the events, but considered neutronic behavior as well where appropriate.

- Panel Chair: Syd Ball - ORNL

- Mike Corradini - U. of Wisconsin

- Randall Gauntt - SNL

- Genvieve Geffraye - CEA

- Yassin Hassan - Texas A\&M

- Dave Moses - ORNL

- Tom Wei - ANL

- Richard Schultz - INL 
- High Temperature Materials Panel - The objectives of the high temperature panel were to assess material behavior under both normal and accident conditions with respect to structural integrity and performance (such as strength, creep, fatigue, and corrosion/erosion properties).

- Panel Chair: Bill Corwin - ORNL

- Ron Ballinger - MIT

- Saurin Majumdar - ANL

- Kevan Weaver - INL

- Graphite Panel - The objectives of the graphite panel were to assess graphite behavior under both normal and accident conditions with respect to structural integrity and performance.

- Panel Chair: Tim Burchell - ORNL

- Rob Bratton - INL

- Barry Marsden - U. of Manchester

- Process Heat \& Hydrogen Panel - The objectives for the process heat PIRT focused on phenomena involved with coupling a hydrogen generation plant to the reactor, mainly those that could affect reactor, not hydrogen plant, safety. Particular phenomena were identified for their role in postulated accident sequences, primarily in terms of external event challenges to the reactor.

- Panel Chair: Charles Forsberg - ORNL

- Max Gorensek - SRNL

- Steve Herring - INL

- Paul Pickard - SNL

- Steve Wright - SNL

- Fission Product Transport Panel - The objectives of the fission product transport PIRT were to categorize potential sources of fission product release and, assuming various release scenarios, identify and rank the primary phenomena involved, as well as the knowledge bases, with respect to the respective FOMs.

- Panel Chair: Bob Morris - ORNL

- Martin Kissane - IRSN

- Robert Morris - ORNL

- Dave Petti - INL

- Dana Powers - SNL

- Bob Wichner-Consultant 


\section{Conduct of Meetings}

Two sets of meetings were held in Rockville, MD. The first meetings were held on February 27 $\& 28,2007$, and the second meetings were held on April 16 through 18, 2007. Handouts and overhead slides from these meetings are available upon request.

\section{February PIRT Meetings}

The first meetings were designed to introduce the panel participants to the NRC's PIRT process and to initiate the first steps in that process. The meetings opened with a PIRT overview (Sud $\mathrm{Basu} / \mathrm{NRC}$ ) and a series of presentations provided by the three principal gas reactor vendors (Areva, General Atomics, and Westinghouse) that covered each design's safety characteristics. Syd Ball (ORNL) then provided an additional overview of gas reactor safety characteristics. The afternoon of the first day and most of the second day was spent by the individual panels identifying gas reactor phenomena (associated with each panel's respective area) and figures of merit. The second day closed with a short session where each panel chair summarized the panel's progress.

\section{April PIRT Meetings}

The second set of meetings allowed the panel members to reconvene and discuss phenomena that were identified during the first meeting. In addition, the remaining steps in the PIRT process were performed. The meetings opened with a review of the PIRT process (with emphasis on the remaining steps to be performed) and a summary of the results from the first meeting (Sud Basu/NRC). The two days were spent by the individual panels completing the remaining steps in the NRC PIRT process. The third day closed with a short session where each panel chair summarized the panel's results.

\section{Additional Panel Meeting}

The Thermal-fluidics Panel was unable to complete their deliberations during the April meetings. Therefore, a supplemental meeting was held during the week of May 1, 2007, at ORNL. This meeting was organized by Panel Chair Syd Ball.

\section{Current Status}

PIRT evaluations were done using the nine-step PIRT process developed by the NRC.

Consideration of a wide range of postulated accidents was based in part on review of licensing and design experience, as well as on detailed accident analysis for designs similar to NGNP (but without the process heat component).

During the PIRT meetings, phenomena with average or consensus rankings of high importance (H) with a corresponding low knowledge level $(\mathrm{L})$ were flagged $(\mathrm{H}, \mathrm{L})$ as the major candidates for further consideration. In some other cases, phenomena ranked $(H, M)$ or $(M, L)$, where $M$ is medium, were given consideration as well. In a very few cases, phenomena ranked $(\mathrm{H}, \mathrm{H})$ or $(\mathrm{M}, \mathrm{M})$ were identified also for consideration, only to indicate that in these cases there was a 
divergence of expert opinions. The list of phenomena in each of the major topical areas is provided in the attached tables. Please note that the results from the High Temperature Materials Panel and the Graphite Panel have been consolidated into one table.

Subsequent to the PIRT meetings, each of the panel members developed the underlying bases for their identification and ranking of phenomena. Input was provided to each respective panel chair that was responsible for organizing the panel's results and for providing those results to the NRC facilitators.

The products of the PIRT activities are documented in five individual PIRT reports, and summarized in a main report. The individual reports are undergoing internal review and the main report is in preparation. These reports will be published as NUREG reports with a tentative publication date of September 2007.

\section{References}

1. D. J. Diamond, Brookhaven National Laboratory, "Experience Using Phenomena Identification and Ranking Technique (PIRT) for Nuclear Analysis," presented at PHYSOR2006 Topical Meeting, Vancouver, British Columbia, Canada, September 10-14, 2006.

The following attachments are included as supporting information in these areas:

- Phenomena Ranking Tables for each of the panel topics.

- Agendas for the February and April PIRT meetings.

- NRC introductory presentation slides given at the start of the April PIRT meeting. 


\section{Draft \\ R\&D Phenomena Table for a Generic High Temperature Gas Reactor \\ Thermofluids, Accident Analysis, and Neutronics}

\begin{tabular}{|c|c|c|c|}
\hline System/component & Phenomena & Importance & Knowledge \\
\hline Reactor vessel & Flow and thermal properties for mixed gases in vessel & High & High \\
\hline Reactor core & Heat transfer correlations for mixed gases in core & Medium & Medium \\
\hline Reactor cavity & RCCS performance with "gray gas" in cavity & Medium & Low \\
\hline Reactor core & Fuel performance with oxygen attack & High & Medium \\
\hline Core support & Core support structures oxidation & High & Medium \\
\hline Reactor corc & Core oxidation & High & Medium \\
\hline Reactor cavity & RCCS gas stratification and mixing & Medium & Medium \\
\hline Cavity/confinement & Confinement-to-reactor cavity air ingress & High & Medium \\
\hline Reactor cavity & Cavity structural integrity during blowdown & Medium & Medium \\
\hline Reactor cavity & Cavity filtering performance & High & Medium \\
\hline Reactor vessel & Molecular diffusion from cavity to vesscl & High & Medium \\
\hline Reactor vessel & Chimney effects and air ingress & Medium & Medium \\
\hline Reactor vessel & Thermal stratification/mixing in the lower plenum & High & Medium \\
\hline Reactor core & Core effective thermal conductivity & High & Medium \\
\hline Reactor core & Decay heat and distribution vs. time & High & Medium \\
\hline Reactor core & Heatup accident fuel performance modeling & High & Medium \\
\hline Reactor vessel & Hydrodynamics of dust suspension & High & Medium \\
\hline Reactor cavity & Pressure pulse in confincment & High & Mcdium \\
\hline Vessel/cavity & Reactor vessel and cavity air circulation and heat transfer & High & Low \\
\hline Reactor core & Reflectors conductivity and annealing & High & Medium \\
\hline Reactor core & Core barrel emissivity & High & Medium \\
\hline Reactor vessel & Inlet plenum stratification \& plumes & High & Medium \\
\hline Reactor cavity & RCCS spatial heat loadings, heat removal & High & Medium \\
\hline Reactor vessel & Radiant heat transfer from core to vessel head & High & Medium \\
\hline Reactor core & Core coolant flow and properties & High & Medium \\
\hline Reactor core & Core coolant bypass flow & High & Low \\
\hline Reactor core & Core flow distribution changes due to graphite irradiation & Medium & Low \\
\hline
\end{tabular}




\section{Draft}

R\&D Phenomena Table for a Generic High Temperature Gas Reactor

Thermofluids, Accident Analysis, and Neutronics

\begin{tabular}{|c|c|c|c|}
\hline System/component & Phenomena & Importance & Knowledge \\
\hline Reactor core & $\begin{array}{l}\text { Core flow distribution changes due to core barrel geometry changes and } \\
\text { core block stability }\end{array}$ & Medium & Medium \\
\hline Reactor vessel/core & Pebble bed core wall interface effects on bypass flow & High & Low \\
\hline Reactor core & Pebble flow & High & Medium \\
\hline Reactor components & Shutdown cooling system startup transients during core heatup & High & Medium \\
\hline Reactor core & Power and flux profile during nornal operation & High & Low \\
\hline Reactor core & Reactivity-temperature feedback coefficients & High & Low \\
\hline Reactor core & Fuel performance modeling & High & Low \\
\hline $\begin{array}{l}\text { Core/vesse } / \text { confinement } / \mathrm{e} \\
\text { nvironment }\end{array}$ & $\mathrm{Ag}-110 \mathrm{~m}$ release and plateout & High & Low \\
\hline $\begin{array}{l}\text { IHX loop/ confinement } \\
\text { bypass }\end{array}$ & Fission product transport through IHX loop (part of confinement bypass) & High & Medium \\
\hline $\begin{array}{l}\text { Reactor vessel and } \\
\text { components }\end{array}$ & $\begin{array}{l}\text { Ingress of molten salt into primary system and RPV; riser and lower } \\
\text { plenum fill }\end{array}$ & High & Medium \\
\hline Reactor vessel & Molten salt to core support/vessel heat transfer & High & Medium \\
\hline Reactor vessel & Reactor cavity to vessel air ingress & High & Medium \\
\hline Reactor cavity & RCCS heat transfer characteristics & High & Medium \\
\hline Reactor cavity & RCCS fouling & High & Medium \\
\hline $\begin{array}{l}\text { IHX loop/ confinement } \\
\text { bypass }\end{array}$ & Helium transport through IHX loop (part of confinement bypass) & Medium & Medium \\
\hline Reactor vessel & Outlet plenum flow distribution & High & Low \\
\hline Core/vessel & Side reflector/core barrel/vessel heat transfer & Medium & Medium \\
\hline Components & Thermal shock in SCS due to startup flow transient & Medium & Medium \\
\hline Reactor core & Reactivity insertion due to pebble core compaction & Medium & Medium \\
\hline Reactor core & Reactivity insertion due to steam/water ingress & High & Medium \\
\hline Reactor core & Control and scram rods, and reactor shutdown worth & High & Medium \\
\hline Reactor core & Xenon and Samarium buildup & Medium & Medium \\
\hline Reactor core & Coolant flow restart during ATWS & Medium & Low \\
\hline
\end{tabular}




\section{Draft \\ R\&D Phenomena Table for a Generic High Temperature Gas Reactor High Temperature Materials and Graphite}

\begin{tabular}{|c|c|c|c|}
\hline System/component & Phenomena & Importance & Knowledge \\
\hline Reactor vessel & Long-term thermal aging of $\mathrm{Gr} .91$ material & High & Medium \\
\hline Reactor vessel & Short-term high temperature thermal aging Gr. 91 material & Medium & Medium \\
\hline Reactor vessel & Crack initial and subcritical crack growth Gr. 91 material & High & Low \\
\hline Reactor vessel & Radiation degradation of $\mathrm{Gr} .91$ material & High & Low \\
\hline Rcactor vessel & Emissivity degradation due to loss of desired surface layer properties & High & Low \\
\hline Reactor vessel & Transient creep in Gr. 91 and LWR materials & Medium & Medium \\
\hline Reactor vessel & Creep during normal operations Gr. 91 material & Medium & Low \\
\hline Reactor vessel & Field fabrication process control & High & Low \\
\hline Reactor vessel & Properties control in heavy sections & High & Low \\
\hline Vessel internals & Radiation induced degradation of control rods & Medium & Medium \\
\hline Vessel internals & Oxidation of control rods & Medium & Medium \\
\hline Vessel internals & $\begin{array}{l}\text { Structural design methodology limitation for C-C composites for control } \\
\text { rods and RPV internals }\end{array}$ & High & Low \\
\hline Vessel internals & Change in emissivity of RPV internals & High & Low \\
\hline Vessel internals & Radiation induced creep of RPV internals & High & Low \\
\hline Vessel internals & Radiation induced embrittlement of RPV internals & Medium & Medium \\
\hline Vessel internals & Environmental and radiation degradation of RPV internals (non-metallic) & High & Low \\
\hline Vessel internals & Oxidation of RPV internals & Medium & Medium \\
\hline Reactor components & Isolation valve failure & High & Low \\
\hline Reactor cavity & Inadequate heat removal & High & High \\
\hline $\begin{array}{l}\text { Power conversion vessel } \\
\& \text { components }\end{array}$ & Missile failure & Medium & Medium \\
\hline $\begin{array}{l}\text { Power conversion vessel } \\
\& \text { components }\end{array}$ & Creep, creep crack growth, thermal loading, fatigue & Medium & Medium \\
\hline $\begin{array}{l}\text { Power conversion vessel } \\
\& \text { components }\end{array}$ & Primary coolant contamination & Medium & Medium \\
\hline $\begin{array}{l}\text { Intermediate heat } \\
\text { exchanger }\end{array}$ & Crecp, fatiguc, subcritical crack growth & High & Low \\
\hline
\end{tabular}




\section{Draft \\ R\&D Phenomena Table for a Generic High Temperature Gas Reactor \\ High Temperature Materials and Graphite}

\begin{tabular}{|c|c|c|c|}
\hline System/component & Phenomena & Importance & Knowledge \\
\hline $\begin{array}{l}\text { Intermediate heat } \\
\text { exchanger }\end{array}$ & Design methodology limitation for structures and components & High & Low \\
\hline $\begin{array}{l}\text { Intermediate heat } \\
\text { exchanger }\end{array}$ & Manufacturing phenomena, inspection and testing & High & Low \\
\hline $\begin{array}{l}\text { Intermediate heat } \\
\text { exchanger }\end{array}$ & Water or chemical ingress/attack & Medium & Medium \\
\hline Other components & Primary coolant contamination in circulators & Medium & Medium \\
\hline Other components & Creep, fatigue, subcritical crack growth & Medium & Medium \\
\hline Other components & Aging fatigue, environmental degradation of piping & High & Low \\
\hline Other components & Creep, fatigue, subcritical crack growth & Medium & Medium \\
\hline $\begin{array}{l}\text { Reactor core and } \\
\text { components }\end{array}$ & Statistical variation of non-irradiated graphite properties & High & Medium \\
\hline $\begin{array}{l}\text { Reactor core and } \\
\text { components }\end{array}$ & Consistency in graphite properties over the reactor life & High & Medium \\
\hline $\begin{array}{l}\text { Reactor core and } \\
\text { components }\end{array}$ & NDE techniques for detection of flaws in graphite & Medium & Medium \\
\hline $\begin{array}{l}\text { Reactor core and } \\
\text { components }\end{array}$ & Fatigue of graphite core components & Medium & Medium \\
\hline $\begin{array}{l}\text { Reactor core and } \\
\text { components }\end{array}$ & Irradiation induced dimensional changes in graphite & High & Medium \\
\hline $\begin{array}{l}\text { Reactor core and } \\
\text { components }\end{array}$ & Irradiation induced creep & High & Low \\
\hline $\begin{array}{l}\text { Reactor core and } \\
\text { components }\end{array}$ & Irradiation induced thermal conductivity changes & High & Medium \\
\hline $\begin{array}{l}\text { Reactor core and } \\
\text { components }\end{array}$ & Irradiation induced changes in elastic constants & High & Medium \\
\hline $\begin{array}{l}\text { Reactor core and } \\
\text { components }\end{array}$ & Irradiation induced changes in CTE & High & Low \\
\hline $\begin{array}{l}\text { Reactor core and } \\
\text { components }\end{array}$ & Irradiation induced changes in mechanical properties & High & Low \\
\hline $\begin{array}{l}\text { Reactor core and } \\
\text { components }\end{array}$ & Annealing of graphite thermal conductivity & Medium & Medium \\
\hline $\begin{array}{l}\text { Reactor core and } \\
\text { components }\end{array}$ & Graphite dust generation & Medium & Low \\
\hline
\end{tabular}


Draft

R\&D Phenomena Table for a Generic High Temperature Gas Reactor High Temperature Materials and Graphite

\begin{tabular}{|l|l|l|l|}
\hline System/component & Phenomena & Importance & Knowledge \\
\hline $\begin{array}{l}\text { Reactor core and } \\
\text { components }\end{array}$ & Tribology of graphite in helium environment & High & Medium \\
\hline $\begin{array}{l}\text { Reactor core and } \\
\text { components }\end{array}$ & Degradation of thermal conductivity of graphite & High & Medium \\
\hline $\begin{array}{l}\text { Reactor core and } \\
\text { components }\end{array}$ & Graphite spalling & High & Low \\
\hline $\begin{array}{l}\text { Reactor core and } \\
\text { components }\end{array}$ & Channel distortion & Medium & Medium \\
\hline $\begin{array}{l}\text { Reactor core and } \\
\text { components }\end{array}$ & Increased bypass coolant flow channels by breaks & Medium & Medium \\
\hline $\begin{array}{l}\text { Reactor core and } \\
\text { components }\end{array}$ & Effect on chronic chemical attack on graphite properties & Medium & Medium \\
\hline
\end{tabular}


Draft

R\&D Phenomena Table for a Generic High Temperature Gas Reactor

Process Heat Applications

\begin{tabular}{|l|l|l|l|}
\hline System/component & Phenomena & Importance & Knowledge \\
\hline $\begin{array}{l}\text { Intermediate heat } \\
\text { exchanger }\end{array}$ & $\begin{array}{l}\text { Blowdown effects, large mass transfer, and pressurization of primary and } \\
\text { secondary sides due to IHX failure }\end{array}$ & High & Medium \\
\hline Process heat exchanger & Fuel and primary system corrosion due to PHX failure & High & Medium \\
\hline Process heat components & Cyclic loading due to temperature transients & Medium & Medium \\
\hline Reactor core & Reactivity spike due to neutron serialization & High & Medium \\
\hline Other components & Turbo machinery response due to mass addition to reactor & Medium & Medium \\
\hline Reactor core and internals & Chemical attack of TRISO layers and graphite & High & Medium \\
\hline $\begin{array}{l}\text { Intermediate heat } \\
\text { exchanger }\end{array}$ & Loss of heat sink and loading of IHX & High & Medium \\
\hline $\begin{array}{l}\text { Intermediate heat } \\
\text { exchanger }\end{array}$ & Radiologic release through IHX loops and plant & Medium & Medium \\
\hline
\end{tabular}




\section{Draft}

\section{R\&D Phenomena Table for a Generic High Temperature Gas Reactor Fission Product Transport and Dose}

\begin{tabular}{|c|c|c|c|}
\hline System/component & Phenomena & Importance & Knowledge \\
\hline Reactor core & Material and structural properties of graphite & High & Medium \\
\hline Reactor core & Graphite geometry and dimensional changes due to air ingress & High & Medium \\
\hline Reactor core & Thermofluids properties & High & Medium \\
\hline Reactor core/vessel & Gas composition for oxygen potential and chemical activity & High & Medium \\
\hline Reactor vessel & Gas flow path & High & High \\
\hline Reactor core/vessel & FP Plate-out and dust distribution under normal operation & High & Low \\
\hline Reactor core/vessel & Matrix permeability and tortuosity & High & Low \\
\hline Reactor core/vessel & Fission product transport through matrix & High & Low \\
\hline Reactor core & Fucl block permeability, tortuosity & High & Medium \\
\hline Reactor core & Fission product transport through fuel block & High & Medium \\
\hline Reactor core/vessel & Sorbtivity of graphite & High & Medium \\
\hline Reactor core/vessel & Fluence effect on transport in graphite & High & Medium \\
\hline Reactor core/vessel & Air/steam attack on graphite & High & Medium \\
\hline Reactor core/vessel & Fission product Speciation in carbonatious material & High & Low \\
\hline Reactor vessel & Fission product Speciation during mass transfer & High & Medium \\
\hline Reactor core/vessel & Dust generation & High & Medium \\
\hline Reactor vessel & Fission product absorption in dust & High & Medium \\
\hline $\begin{array}{l}\text { Reactor vessel/ } \\
\text { components }\end{array}$ & Tritium generation and circulating coolant inventory & High & Medium \\
\hline Vessel/confinement & Ag- $110 \mathrm{~m}$ generation, transport & High & Low \\
\hline Vessel/confinement & Aerosol growth & High & Low \\
\hline Vessel/confinement & Surface roughness effect on aerosol deposition & Medium & Medium \\
\hline Vessel/confinement & Coolant chemical interaction with surfaces & High & Medium \\
\hline Vessel/confinement & FP diffusivity, sorbtivity in non-graphite surfaces & High & Low \\
\hline Vessel/confinement & Aerosol/dust deposition & High & Medium \\
\hline Vessel/confinement & Aerosol dust bounce, breakup during deposition & High & Medium \\
\hline
\end{tabular}




\section{Draft}

R\&D Phenomena Table for a Generic High Temperature Gas Reactor

Fission Product Transport and Dose

\begin{tabular}{|l|l|l|l|}
\hline System/component & Phenomena & Importance & Knowledge \\
\hline Vessel/confinement & Resuspension of fission products & High & Low \\
\hline Confinement & Confinement aerosol physics & High & Medium \\
\hline Vessel/confinement & Fission product and aerosol wash-off & High & Medium \\
\hline Other components & Failure modes of auxiliary systems (e.g. gas cleanup, holdup, refueling) & Medium & Medium \\
\hline Confinement & Radiolysis effects in confinement & High & Medium \\
\hline Confinement & Combustion of dust in confinement & High & Medium \\
\hline Confinement & Confinement leakage path, release rate through penetrations & High & Medium \\
\hline Other components & Cable pyrolysis, fire & High & Medium \\
\hline Reactor core & Recriticality (slow) & High & Medium \\
\hline Reactor core & Fuel-damaging reactivity insertion accidents & High & Medium \\
\hline
\end{tabular}




\section{First NGNP PIRT Meeting Doubletree Hotel, Rockville February 27-28, 2007}

\section{Day\#1 (Tuesday, Feb. 27)}

8:30 Opening remarks

8:40 Introduction to NGNP PIRT

9:10 Overview of NGNP

9:30 Industry presentation by Westinghouse

10:00 Industry presentation by AREVA

10:30 BREAK

10:45 Industry presentation by General Atomics

11:15 Modular HTGR safety and accident characteristics

12:30 LUNCH BREAK

1:30 PIRT Breakout Sessions (4 parallel sessions)

a. Panel Chairs' presentations

b. Individual member presentations (optional)

c. Initial PIRT development

d. Issue identification for group discussion
F. Eltawila (NRC)

$\mathrm{S}$. Basu (NRC)

T. Cook (DOE)

C. Kling (WEC)

F. Shahrokhi (AREVA)

J. Parme (GA)

S. Ball (ORNL)

\section{5:30 ADJOURN}

\section{$\underline{\text { Day \#2 (Wednesday, Feb. 28) }}$}

8:30 PIRT Breakout Sessions continued

PIRT Chairs

12:30 LUNCH BREAK

1:30 PIRT Breakout Sessions continued PIRT Chairs

3:00 Meeting wrap-up

a. PIRT Chairs' reports

b. Discussion

c. NRC assessments and guidance

d. Date and location for the final PIRT meeting

\section{4:00 ADJOURN}




\section{Second NGNP PIRT Meeting \\ Doubletree Hotel, Rockville \\ April 16 - 18, 2007}

\section{Day\#1 (Monday, April 16)}

1. $9: 00$ Opening Remarks

NRC/DOE

2. 9:10 Summary of the First NGNP PIRT Meeting

S. Basu (NRC)

3. $9: 30$

Panel Summaries

Thermofluids and Accident Analysis

S. Ball (ORNL)

High Temperature Materials

Graphite

K. Weaver (INL)

T. Burchell (ORNL)

Process Heat Applications

C. Forsberg (ORNL)

Fission Products

R. Morris (ORNL)
4. 10:30 BREAK
5. 11:00 PIRT Breakout Sessions
6. $12: 00$ LUNCH
7. 1:00 PIRT Breakout Sessions (continued)
Interaction between panels

PIRT Chairs

PIRT Chairs

8. $5: 00$

ADJOURN

\section{Day \#2 (Tuesday, April 17)}

1. $8: 30$ PIRT Breakout Sessions continued

PIRT Chairs

2. $12: 00$ LUNCH

3. 1:00 PIRT Breakout Sessions continued

PIRT Chairs

4. 3:00 BREAK

5. 3:30 PIRT Breakout Sessions continued

6. 5:30 ADJOURN

PIRT Chairs

\section{$\underline{\text { Day \#3 (Wednesday, April 18) }}$}

1. $8: 30$ PIRT Breakout Sessions continued

PIRT Chairs

2. 10:30 BREAK

3. 11:00 PIRT Breakout Sessions continued

PIRT Chairs

4. 12:00 LUNCH

5. 1:00 PIRT Wrap-Up

a. PIRT Chairs' reports

b. Discussion

6. 3:00 ADJOURN 


\section{PIRT Meeting 2 - NRC Introduction - Sudhamay Basu}

\section{SECOND NGNP PIRT}

Sudhamay (Sud) Basu, NRC

- Hardware and Scenarios specified (Step 3)

- Identify NGNP hardware/plant including components (e.g., reactor vessel, core, internals. IHX, etc.)

- Identify conditions (accident and otherwise) to which plant and components ore exposed

- Evaluation Criteria (FOM) established (Step 4)

- Top level regulatory criteria (e.g., dose limit) common to ail panels

- Criteria at subsidiary levels established by individual panels: criteria may be different for panels but all

derivatives of top level regulatory criteria

- Existing Knowledge Base discussed (Step 5)

- Background information capturing relevant

knowledge

- HTGR legacy information

- Industry resources

- Ongaing international activities

- Relevant Phenomena identified (Step 6)

- All plausible phenomena without importance ranking

- Connectivity between phenomena, scenarios, and hardware

\section{Summary of the First NGNP PIRT}

- Issue dafined (Step 1)

- NGNP is a new design (VHTR, dud mission)

- Experience base (design, operation)

- Knowledige base (data, tools, etc.)

- Objectives defined (Step 2)

- Identify safety-relevant phenomena, rank importance.

and assess knowledge base

- Major topical oreas covered

* Themofluidics and accident analysis (including neutronics)

- High temperature materials including graphite

* Process heat and hydrogen co-generation

* Fission product transport and dose

\section{Evaluation Criteria (FOM)}

\begin{tabular}{|c|c|c|c|c|c|}
\hline FOA Level & TF & H.T. Mat'l & Grophite & Process & FPT \\
\hline $\begin{array}{l}\text { Level I } \\
\text { (regulatory) }\end{array}$ & Dose & Dose & Dose & Dose & Dose \\
\hline $\begin{array}{l}\text { Level } 2 \\
\text { (system) }\end{array}$ & $\begin{array}{l}\text { Fuel } \\
\text { failure } \\
\text { fraction }\end{array}$ & $\begin{array}{l}\text { System/ } \\
\text { structure } \\
\text { integrity }\end{array}$ & $\begin{array}{l}\text { Coolable } \\
\text { geometry }\end{array}$ & $\begin{array}{l}\text { Structure } \\
\text { integrity }\end{array}$ & $\begin{array}{l}\text { Cumul Fp } \\
\text { releose } \\
\text { history }\end{array}$ \\
\hline $\begin{array}{l}\text { Level } 3 \\
\text { (component) }\end{array}$ & $\begin{array}{l}\text { RPV P\&T } \\
\text { timits }\end{array}$ & $\begin{array}{l}\text { RPV } \\
\text { integrity }\end{array}$ & $\begin{array}{l}\text { Reactivity } \\
\text { control }\end{array}$ & $\begin{array}{l}\text { Equiprnent } \\
\text { integrity }\end{array}$ & \\
\hline $\begin{array}{l}\text { Level } 4 \text { (sub- } \\
\text { component) }\end{array}$ & $\begin{array}{l}\text { Cootant } \\
\text { octrivity } \\
\text { level }\end{array}$ & $\begin{array}{l}\text { Heat } \\
\text { transfer } \\
\text { capablify }\end{array}$ & & $\begin{array}{l}\text { Chemical } \\
\text { corrosion }\end{array}$ & \\
\hline
\end{tabular}

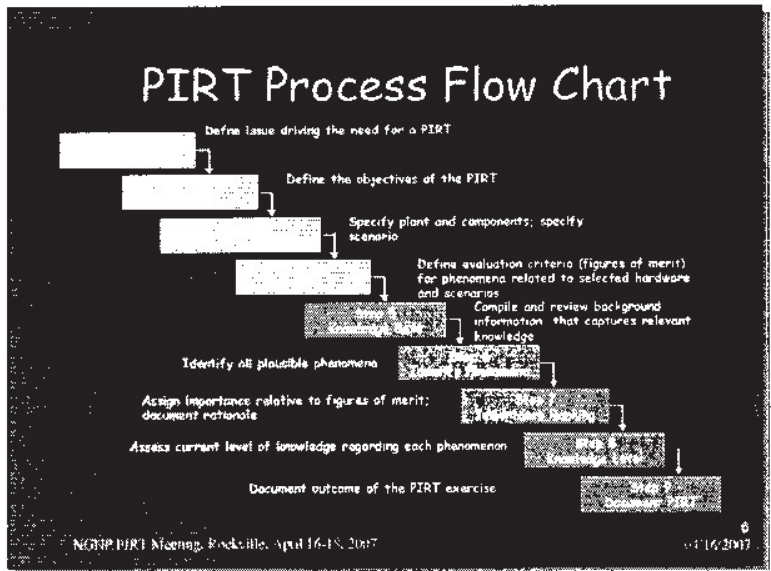




\section{PIRT Premise}

- PIRT provides for identification and ranking of safety-significant phenomena

- Some phenomena are more important than others; some phenomena are not as important

- Once phenomena are ranked by importance, research needs can be prioritized to address highly-ranked important phenomena with least knowledge base

\section{Remaining PIRT Process}

- Step 6-Phenomena Identification (revisited)

- Panel re-examines the list of plausible phenomena for completeness

- Staff input solicited and provided for panel consideration

- Interaction between panels for consistency

\section{Remaining PIRT Process}

- Step 7 - Phenomena Importance Rankıng - Basis for ranking

Influence on satety, measured with respect to established evaluation criter'la or FOM Improved under'standing needed for making
decisions of interest

- Ranking scole and rationale $H \mathrm{H} G H(\mathrm{H})$ if pheromeron has controlling mifluence on FOM or improved under'starding critical for making decisions MEDTUM (M) if moderate influer.ce on FOM o improved under'standing importart for making decisions

LOW (L) if munmal influence on FOM or current understanding adequate for makiriy decisiors

\section{Remaining PIRT Process}

- Step 8-Knowledge Assessment

- Definition

Understanding of physical phenomena

Associated expermentol data base models or onalytical tools

- Assessment ranking and rationale KNOWN (K)/HTGH (H) if the knowledge base of a phenomenor is adequate for modeling ariolyticul representation. or mahing decisions of intescest PARTIALLY KNOWN (PK)/MEUIUM $(M)$ if the krowledge base is incomplete for the above purposes

UNKNNOWN (U)/LOW (L) if none or hardly ary knowledge exists by way of physics, dota, or mudel

\section{Phenomena Ranking Template}

\begin{tabular}{|c|c|c|c|c|c|}
\hline Phenoniena & $\begin{array}{l}\text { Sofety } \\
\text { relevence }\end{array}$ & $\begin{array}{l}\text { Finplort arice } \\
\text { rankirig }\end{array}$ & Ratisnale & $\begin{array}{l}\text { Kinostedge } \\
\text { assess }\end{array}$ & Rationtale \\
\hline $\begin{array}{l}\text { Radiation } \\
\text { heat } \\
\text { trunsfer }\end{array}$ & $\begin{array}{l}\text { Heat load } \\
\text { to upper } \\
\text { head }\end{array}$ & $\begin{array}{l}\text { High }(H) \\
\text { median }(M) \\
\text { or lovi: (l.) }\end{array}$ & $\begin{array}{l}\text { Relntrive } \\
\text { conttintuat } \\
\text { of to beat } \\
\text { loas }\end{array}$ & 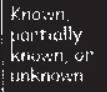 & $\begin{array}{l}\text { Existiny } \\
\text { deta } \\
\text { tonls, ete. }\end{array}$ \\
\hline $\begin{array}{l}\text { Thermal } \\
\text { cging }\end{array}$ & $\begin{array}{l}\text { RPV } \\
\text { integrity }\end{array}$ & $H, M$, or $\mathrm{t}$ & ….... & & \\
\hline $\begin{array}{l}\text { Hydrogen } \\
\text { blast } \\
\text { effect }\end{array}$ & $\begin{array}{l}\text { Strut ture } \\
\text { integrify }\end{array}$ & $H, M, a r l$ & $\cdots \cdots$ & 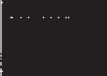 & \\
\hline $\begin{array}{l}\text { F arid } \\
\text { dist plate - } \\
\text { out }\end{array}$ & $\begin{array}{l}\text { Il' and } \\
\text { dust } \\
\text { trakisport }\end{array}$ & $H A$ or $L$ & $\ldots \ldots$ & & ...... \\
\hline
\end{tabular}

\section{Remaining PIRT Process}

- Step 9 - Documentation

- PIRT objectives

- Process description

- Discussion of hardware, scenarios, evaluation factors (FOM)

- Listing of plausible phenoments

- Individual scoring of phenomena importarice and knowledge assessment

- Collective (panel) scoring

- Detail discussion of scoring rationale

- Supporting reference materials 